\title{
US - Section 110(5) Copyright Act United States - Section 110(5) of the US Copyright Act, Recourse to Arbitration under Article 25 of the DSU: Would've or Should've? Impaired Benefits due to Copyright Infringement*
}

GENE M. GROSSMAN AND PETROS C. MAVROIDIS

\section{Facts of the case}

This dispute between the European Communities and the United States originated when the United States amended its copyright law in a way that nullified and impaired certain benefits promised to the European Communities under the Agreement on Trade Related Aspects of Intellectual Property (TRIPs). Article 9.1 of TRIPs requires all WTO members to comply with Articles 1 through 21 of the Berne Convention of 1971. Among the provisions of the Berne Convention thus incorporated into the TRIPs Agreement is one that grants to authors of literary and artistic works the exclusive right to authorize "the public communication by loudspeaker or any analogous instrument transmitting, by signs, sounds or images, the broadcast of the work," and another that grants to authors of dramatic and musical works the exclusive right to authorize "any communication to the public of the performance of these works."

In 1998, the United States amended its Copyright Act of 1976 to expand substantially the exemption enjoyed by certain establishments from the obligation to pay royalties on some copyrighted music. ${ }^{2}$ Subparagraph (A) of amended Section 110(5) of the US Copyright Act exempts

\footnotetext{
* This study was prepared for the American Law Institute project on "The Principles of World Trade Law." We are grateful to Yves Renouf and Hannu Wager for helpful discussions and to Jane Ginsburg, Alice Haemmerli, and participants at the ALI conference held in Philadelphia, PA on February 6-7, 2003, for their comments on earlier drafts of this paper.

${ }^{1}$ See Article 11bis(1)(iii) and Article 11(1)(ii) of the Berne Convention (1971).

2 See the Fairness in Music Licensing Act of October 27, 1998.
} 
eating, drinking, and retail establishments that transmit music on a single receiving apparatus of the kind commonly used in private homes (this part of Section 110(5) remains essentially unchanged from its previous version). Sub-paragraph (B) excludes, on the one hand, bars and restaurants of less than 3,750 square feet that transmit radio and television music as well as larger bars and restaurants that communicate audio performances by means of six or fewer loudspeakers, or audiovisual performances by means of four or fewer audiovisual devices ((B)(ii) - (B)(iv)) and on the other hand establishments other than bars and restaurants ((B)(i), referred to as retail establishments). ${ }^{3}$

The European Communities challenged the legality of the US policy before a WTO Panel, using the dispute settlement procedures outlined in the Understanding on Rules and Procedures Governing the Settlement of Disputes (hereafter, the DSU). The European Communities claimed that the US amendment to Section 110(5) had denied holders of EC rights benefits that were promised to them by TRIPs. The European Communities objected to both the exemptions under sub-paragraph (A) for small establishments using one receiver and to the exemption under sub-paragraph (B). It should be noted that (B)(i) applies to all retail establishments, whereas (B)(ii)-(B)(iv) apply to all eating and drinking establishments. The European Communities in their complaint presented claims and arguments on all categories of sub-paragraph (B). The Panel upheld the EC claim with respect to sub-paragraph (B) of Section 110(5), while ruling that sub-paragraph (A) does not violate any WTO statutes. Neither side appealed the ruling.

The DSU (Article 22.1) allows a Member in violation of a WTO obligation to pay compensation to an injured Member to settle any dispute when both sides agree on the amount. ${ }^{4}$ In case the parties cannot agree on a level of compensation, and if the offending Member continues policies that have been found to be in violation of the WTO Agreement, the WTO may authorize an equivalent withdrawal of concessions by the injured Member. In the case at hand, the United States and the European Communities met following the issuance of the Panel Report to discuss potential compensation. When they could not come to an agreement, they

\footnotetext{
${ }^{3}$ Non-eating and drinking establishments are also permitted under new sub-paragraph (B) to use up to six loudspeakers for audio, and up to four audiovisual devices for audiovisual performances. Although the amendment includes some limitations on the number of devices that can be placed in one room, it represents a radical enlargement in Section 110(5)'s scope. The 3,750 square feet statutory delimitation does not apply to retail establishments.

4 The offending Member is still, however, obligated to bring its policies into conformity with WTO rules within a reasonable period of time.
} 
turned to the WTO for binding arbitration to resolve the issue. The possibility of such arbitration was established in Article 25.2 of the DSU, which states in part that "except as otherwise provided in this Understanding, resort to arbitration shall be subject to mutual agreement of the parties which shall agree on the procedures to be followed." Article 25.3 further stipulates that "the parties to the proceedings shall agree to abide by the arbitration award."

The European Communities argued before the Arbitrators that the United States ought to pay compensation equal to the full amount of the royalties that would have been paid by US eating and drinking establishments of less than 3,750 square feet had all of them been duly licensed to transmit the copyright-protected music. It estimated this amount to be $\$ 25,486,974$.

The United States countered that the actual level of benefits that had been nullified or impaired was dramatically smaller than this, amounting to somewhere between $\$ 446,000$ and $\$ 733,000$. It justified this smaller figure in two steps. First, it noted, not all of the eating and drinking establishments that might potentially be licensed actually pay royalties. Royalties are collected in the United States on behalf of copyright holders by collective management organizations. These organizations do not find it profitable to license all of the potential users of their works in view of the transactions costs that are involved. Indeed, in the years that immediately preceded the passage of the amendment to Section 110(5)(B), less than 20 percent of restaurants in the United States were licensed to transmit music, whereas almost three quarters of restaurants actually did play music.

Second, the United States argued, the impaired benefits of the European Communities should include not the gross amount of royalties that copyright holders would have collected but only the net payments copyright holders would have received from the collective management organizations had the licensing of small restaurants and bars taken place. The difference of course is the fees that would have been retained by the collective management organizations, which are two American corporations. ${ }^{5}$ In effect, the European Communities requested compensation for the totality of royalties that should have been collected, whereas the United States asked that compensation be limited to the amount that would have been paid.

\footnotetext{
5 These are the American Society of Authors, Composers and Publishers (ASCAP) and Broadcast Music Inc. (BMI). A third CMO, the Society of European Stage Authors and Composers is also active in the industry, but the parties and the Arbitrators did not include this organization in its calculations because they considered the royalties it pays to EC rights holders affected by this dispute to be insignificant.
} 


\section{The WTO Arbitration process}

Before turning to the legal and economic issues involved in this case, it will be useful for us to discuss briefly the legal mandate of the WTO Arbitrators and the role that they are meant to play in the dispute settlement process.

As we noted in section 1, the possibility of arbitration as an alternative means of dispute resolution was introduced in Article 25 of the DSU. The appeal of the arbitration alternative presumably lies in its streamlined proceedings and in the prospect it offers to avert any mutually damaging retaliatory measures. Article 25 leaves the procedures to be followed by the Arbitrators as a matter to be agreed by the disputing parties. It places few restrictions on either the nature of the issues that can be considered or the reasoning that must be applied. ${ }^{6}$ Moreover, the matter under consideration was the first time that WTO Members had resorted to the arbitration process after the adoption of the DSU. Precedents and prior jurisprudence are thus non-existent in this case.

The parties to the copyright dispute asked the Arbitrators to rule only on the size of the payment that the United States would make to the European Communities to compensate for its violation of TRIPs. In principle, the parties might have gone to the Arbitrators in lieu of pursuing their initial dispute before the WTO Panel. They might also have asked the Arbitrators to rule on whether the US enforcement procedures for copyright infringement are consistent with its obligations under TRIPs, an issue that we will touch upon later. But they did not elect to do either; instead, they limited the Arbitrators' mandate to one of quantifying the level of compensation. The Arbitrators, for their part, were not legally obliged to accept this mandate, inasmuch as the text of Article 25 of DSU does not address the issue of how the Arbitrators' mandate shall be determined. But neither does the DSU prohibit the parties from restricting the scope of the arbitration hearing. In the event, the Arbitrators accepted their limited mandate.

Given this mandate, the Arbitrators had few guidelines to follow in reaching a decision. Unlike in cases involving the suspension of concessions - which arise when the WTO adjudicating body finds in favor of a complainant and the offending party fails to change its practices so as to comply with the WTO rules - the DSU places no restriction on the size of any compensation payment, and in particular does not limit

${ }^{6}$ Article 25.4 of the DSU does require that "Articles 21 and 22 of the DSU shall apply mutatis mutandis to the arbitration awards." 
compensation to the amount of the benefits that have been nullified or impaired. Article 25 of the DSU is also silent on the issue of punitive compensation and on the question of whether compensation should be paid retroactively (from the time that the offending party began to violate the WTO Agreement) or prospectively (from the time that the injured party filed its complaint). Article 25.3 of the DSU does require, however, that the parties abide by the Arbitrators' decision without recourse to appeal.

\section{The Arbitrators' decision}

\subsection{The parties' arguments}

As mentioned previously, the European Communities requested that compensation be set equal to the economic value of the exclusive rights that the United States denied to EC holders when it granted an exemption from royalties to small bars and restaurants. The value of these rights, it submitted, is the full amount of royalties that the establishments would have paid for the use of radio and television music copyrighted by EC rights holders had the TRIPs Agreement been perfectly enforced by the United States. To do less, the European Communities claimed, would be tantamount to sanctioning piracy.

The European Communities arrived at its estimate of the foregone licensing revenue using a "bottom-up" approach. It took as its starting point an estimate of the number of establishments in the United States that qualify for the exemption under Section 110(5)(B) of the Copyright Act but not Section 110(5)(A). It reduced this number to account for the estimated fraction of establishments that do not play music. For the remaining establishments, it applied the licensing fees found in the fee schedules of the two collective management organizations at the time.

The United States countered that lost benefits ought not to be based on potential revenues, but rather on legitimate expectations. The EC rights holders could not legitimately have expected to receive payments equal to the full potential value of the rights, because there are substantial costs associated with collecting the fees. In actuality, the rights in question are administered by the actions of the collective management organizations. These organizations decide which establishments to license based on a comparison of potential revenues and prospective costs. With respect to larger eating and drinking establishments, the collective management organizations (CMOs) do not in fact choose to collect royalties from every bar or restaurant with over 3,750 square feet of surface area that 
offers music. And prior to the introduction of the exemption for smaller establishments, the CMOs evidently considered it worthwhile to license only a modest fraction of those establishments that were potentially liable for royalty payments.

The United States further argued that the Arbitrators would be granting the European Communities a windfall profit if they disregarded the actual cost of collecting and distributing the royalties. The legitimate expectations of the EC rights holders could include only the net payment they would receive absent the exemption for small eating and drinking establishments, not the gross payments that include a part to cover the cost of doing business for the CMOs.

The United States used a "top-down" approach to estimate the benefits lost by the European Communities. It took as its starting point the total royalties paid to EC rights holders in the years preceding the amendment to Section 110(5) and proceeded to adjust this number by successive reductions to reflect the amount attributable to entities that do not meet the statutory definition of an "establishment," the amount due to music from sources other than radio and television, and the amount due to eating and drinking establishments that do not meet the size and equipment limitations of Section 110(5)(B) that would qualify them for an exemption.

\subsection{The Arbitrators' reasoning}

The Arbitrators basically concurred with the conceptual arguments put forth by the United States, although they did not accept all aspects of the US calculation of impaired benefits.

The Arbitrators noted that the benefits nullified or impaired by the US policy are not limited to the royalties lost by EC copyright holders. In principle, other EC citizens besides the rights holders might have suffered as a result of the US failure to abide by TRIPs. However, the European Communities had not made any arguments to the effect that there were other losers from the copyright exemption besides the rights holders, so the Arbitrators decided to treat the lost benefits of the EC rights holders and the lost benefits of the European Communities as equivalent.

Next, the Arbitrators ruled that the rights protected by Article 11.1 of the Berne Convention (but violated in part by the United States by dint of its exemptions) should not be considered to be self-enforcing. Enforcement imposes a cost, as is evident from the fact that EC rights holders choose to rely on collective management organizations to assist them 
in collecting their royalty fees. The Arbitrators found force in the US argument that enforcement activities ought to be planned on a cost-benefit basis. The collective management organizations license only those establishments for which the expected revenues exceed the transaction costs.

The Arbitrators were persuaded that revenues and costs of licensing will vary with characteristics of the user base, such as "the number, size and location of the users that play broadcast music as well as the extent to which users play such music" (Award of the Arbitrators, para. 3.29; hereafter, Award). Therefore, the Arbitrators ruled, the transaction costs can legitimately affect the level of licensing. Moreover, the actual size of these costs should not be neglected in calculating the benefits that the rights holders can expect to realize from the TRIPs Agreement.

However, it is not true that TRIPs leaves WTO Members free to choose any enforcement procedures they wish, perhaps thereby rendering the costs of enforcement to be prohibitively large. For intellectual property, the legal environment and the specific transactions costs associated with collecting the fees jointly determine the magnitude of the enforcement costs. Concerning the former, Article 41 of TRIPs obliges a Member to

ensure that enforcement procedures ... are available under their law so as to permit effective action against any act of infringement of intellectual property rights covered by this Agreement.

The European Communities could have challenged the enforcement procedures used by the United States in its complaint to the WTO Panel. However, as the Arbitrators note in footnote 44 of the Award of the Arbitrators, they did not elect to do so. Nor did the parties agree to make the question of whether the US enforcement provisions meet the requirements imposed by TRIPs part of the Arbitrators' mandate in this case. The Arbitrators ruled that it is beyond the scope of their investigation to assess the legality of the enforcement provisions that are included in US copyright law. Instead, they chose to "assume that the United States is acting consistently with the enforcement obligations contained in the TRIPs Agreement" and based their evaluation of the EC claim on the economic implications of the costs present in administering the rights according to the prevailing legal environment.

In short, the Arbitrators concluded that the level of EC benefits that are being nullified or impaired as a result of Section 110(5)(B) of the US Copyright Act is equal to the amount of royalty payments that would have been distributed by US collective management organizations to EC rights holders had the offending amendment not taken effect. They then turned 
to the task of estimating these payments in the hypothetical, "but-for" world.

\subsection{The Arbitrators' calculations}

The Arbitrators essentially adopted the "top-down" methodology proposed by the United States, but did not consider all of its adjustment and deductions to be appropriate. After confirming with the parties that they did not consider the Arbitrators to be bound to choose either one or the other of the party's proposed estimates, the Arbitrators set about to construct their own estimate of the EC benefits nullified or impaired by Section 110(5)(B).

The Arbitrators considered it appropriate to begin with an estimate of the actual licensing revenues paid to EC rights holders by US collective management organizations in the three-year period prior to 1998 , when the Amendment of Section 110(5)(B) illegally extended the scope of exemptions from royalty payments. The first step in their calculation generated an estimate of the average annual amount for 1996 through 1998 of total royalties distributed for the benefit of EC right holders both "directly" (direct distribution by ASCAP and BMI to the EC collecting societies that represent EC musicians and music publishers) and "indirectly" (distribution to US publisher affiliates of EC publishers for the performance of EC works). ${ }^{7}$

Second, they deducted an estimate of the royalties paid on behalf of users other than eating, drinking, and retail establishments. ${ }^{8}$ Third, from the resulting estimate of the total amount paid by the relevant establishments, the Arbitrators deducted an estimate of the amount due to music sources other than radio and television music, since these other sources were not exempted from payment under the amendment to Section 110(5). Fourth, the Arbitrators estimated the share of the revenues attributable to eating, drinking and retail establishments for the broadcast

${ }^{7}$ For ASCAP, the Arbitrators had access to these two categories of payments for the three years in question. For BMI, they had only the direct payments for 1996. They estimated the average annual amount for direct plus indirect payments for BMI by assuming that the ratio of direct to indirect payments and the growth rate of total payments was the same for BMI and for ASCAP.

8 This would include both licensing from radio and television broadcasting and concerts, which are not part of "general licensing," and royalties paid in the general licensing category by users such as airlines, sports stadiums, motion-picture theatres, amusement parks, conventions, telephone-music services, colleges and universities, health clubs, and backgroundmusic services. 
of radio and television music that was due to establishments newly exempted from royalties in 1998 by Section 110(5)(B) of the US Copyright Act. This required an estimate of the fraction of establishments that meet the size limit of 3,750 square feet of surface area and the fraction that are exempted based on the type of broadcast equipment they use.

The resulting figure after all of these deductions represents an estimate of the average annual royalties that were paid by the newly exempted establishments for their rights to broadcast radio and television music during the years 1996 through 1998. The Arbitrators adjusted this figure to allow for growth between that period and July 23, 2001, the date at which the matter was referred for arbitration. Their resulting estimate of the benefits nullified or impaired by dint of Section 110 (5)(B) is $\$ 1,100,000$ per year.

\subsection{No punitive compensation and no retroactive payments}

As we noted previously, the DSU is silent on the question of whether compensation should include any amount for punitive purposes and whether the injured party should be compensated retroactively for illegal actions that took place prior to the initiation of its complaint. The Arbitrators ruled that punitive compensation would be inappropriate in this case, because they would lead to a situation in which "the level of E.C. benefits nullified or impaired by the operation of Section 110(5)(B) would have been overestimated" (Award, para. 4.27). They did, however, recognize in footnote 84 of the Award that an overestimation of benefits is less consequential for matters of compensation than for matters involving the withdrawal of concessions, because Article 22.7 of DSU does not specify that compensation paid under Article 22.2 of DSU must be equivalent to the level of nullification or impairment.

The Arbitrators' decision on whether compensation should be prospective or retroactive was less explicit, but can be gleaned from their method of calculation. Nowhere did they rule on whether it would be appropriate for the United States to compensate the European Communities for nullified or impaired benefits incurred between the amendment of Section 110(5)(B) and the date at which the matter was referred to arbitration. But in calculating the size of the lost benefits, the Arbitrators allowed for growth in the but-for royalties between the historical period prior to the enactment of Section 110(5)(B) and July 23, 2001, the date at which the matter was referred for arbitration. They did not compute any estimate of what benefits had been nullified or impaired in the intervening 
period. Evidently, they meant their remedy to be prospective from the date of referral and not to include any compensation for the prior period.

\section{Analysis and critique of the Arbitrators' decision}

In this section, we shall analyze and critique the Arbitrators' decision. We begin by examining the objectives of TRIPs and discuss the strength of the protection of intellectual property rights that it is meant to provide. We briefly touch on the issue of optimal enforcement policy, but conclude as the Arbitrators did that the legality of the US enforcement provisions is beyond the scope of our task. We then turn to the principles the Arbitrators should have used in deciding an amount of compensation, once they had assumed that the US enforcement provisions were consistent with the objectives of TRIPs. We conclude that the Arbitrators were correct to evaluate the legitimate expectations of the EC rights holders and to use this as a basis for their compensation award. Finally, we discuss the calculations performed by the Arbitrators and their treatment of the issues of punitive and retroactive compensation.

\subsection{Potential revenues or legitimate expectations?}

TRIPs was designed to prevent Members from imposing negative externalities on their trading partners when they established their national systems for protecting intellectual property. ${ }^{9}$ In a non-cooperative world regime of intellectual property protection, externalities might come in two main forms. First, governments may have a national incentive to discriminate against the intellectual property rights of foreign citizens (see, for example, Scotchmer, 2002). This explains the requirements for national treatment that are included in TRIPs, and in the Berne Convention and Paris Treaty before it. Second, even with national treatment, national governments may choose to provide insufficient protection for intellectual property relative to the strength of protection that would be globally efficient.

What determines the efficient level of protection of intellectual property? In choosing their patent and copyright policies, governments must balance the static costs of protection against dynamic benefits. Once intellectual property exists, it typically can be consumed by many different

${ }^{9}$ For an excellent overview of TRIPs and a detailed analysis of its objectives and provisions, see Maskus (2000). 
users at little or no additional cost beyond the initial cost of creating it. For example, the creation of a new music album requires substantial investment of time and resources by songwriters, performing artists, and musical publishers. The cost of producing an extra compact disc of an existing piece of music is very much smaller. Once a musical work exists, it would be efficient to allow widespread use (without copyright protection) up to the point where the marginal benefit of the last listener matches the marginal cost of stamping out an extra disc. By granting copyright protection to the rights holders, the government induces a monopoly price of the disc in excess of the marginal production cost, thereby generating under-consumption. This is the static cost that derives from government protection of intellectual property.

Against this cost is the dynamic benefit. The presumption is that without any form of protection, the creators of intellectual property would reap little or no personal benefits from their investments in knowledge or art; they might then invest very little. By granting monopoly rights, the government provides private rewards to the creators of intellectual property that serve as an inducement for their efforts. The nationally optimal intellectual property regime is one that balances the marginal cost to national citizens of the distortions that derive from monopoly pricing against the marginal benefit that comes from having a greater stock of knowledge and artwork available.

As Grossman and Lai (2002) show, there are two reasons why intellectual property protection will be too weak when policies are set noncooperatively by national governments. ${ }^{10}$ First, national governments do not take into account in their cost-benefit calculus the benefits that accrue to foreign citizens when protection induces additional investments in intellectual property. Second, national governments do not consider as an offset to the static cost of granting patent and copyright protection the monopoly profits that accrue to foreign rights holders. For both these reasons, a global regime of independently chosen patent and copyright policies will provide too little incentive for investment in intellectual property relative to the aggregate reward that would maximize world welfare. In effect, countries have an incentive to free ride on the intellectual property rights protection provided by their trading partners.

${ }^{10}$ On the related point of whether developing countries have an incentive to grant patent and copyright protection considering that relatively little intellectual property is created by their nationals, see Chin and Grossman (1990), Diwan and Rodrik (1991), Deardorff (1992), and Helpman (1993). 
By forging an international treaty such as TRIPs, the WTO Members can ensure that each takes into account the interests of the others when setting its national policies. Overall, an efficient agreement should serve to strengthen global protection of intellectual property. Various combinations of policies in different countries can achieve the globally efficient level of protection for any particular type of intellectual property. Moreover, in each country, the strength of protection for a particular type of intellectual property reflects a number of different dimensions of the national policy. For musical and dramatic works such as those at issue in this dispute, copyright protection might vary in the number of years for which protection is provided, the breadth of protection against similar but not identical works, the range of uses that are regulated by copyright protection, and the enforcement provisions that are included in case of infringement, among others. For these reasons and others, TRIPs does not stipulate the exact package of policies that must be adopted in each member country.

Instead, TRIPs specifies some minimum standards that all Members must meet in all functional areas of intellectual property protection. On copyrights, as already indicated, TRIPs requires Members to obey many of the rules of the Berne Convention. This means, for example, that governments must grant copyrights that extend for the life of an author plus fifty years. The Agreement also stipulates that Members must protect computer software and data compilations by copyright under the terms of the Berne Convention, just as they would literary works.

At issue in this dispute is the extent and nature of US enforcement of copyright protection. The optimal enforcement policy for the United States - that is, the policy that would maximize world welfare - is not one that ensures licensing to 100 percent of the users of proprietary music. Even if such an objective were feasible, which it probably is not, the costs of ensuring such a high level of compliance would far outweigh the benefits. Rather, the optimal enforcement policy is one that balances the marginal cost of achieving slightly greater compliance with the marginal benefits that derive from doing so. Note that the optimal enforcement policy will vary with the other policy dimensions that are enacted. For example, a change in the duration of copyright protection alters the marginal benefit of greater compliance with the copyright laws and thus the resources that should be devoted to avoiding infringements.

Is the US policy with regard to the playing of music by eating and drinking establishments consistent with TRIPs? The WTO Panel determined 
that it is not, insofar as the US exempts establishments smaller than a certain size from the obligation to license certain music. But even if there were no such exemption, there remains the question of whether an enforcement system that requires the participation of private agents (the collective management organizations) and achieves a relatively modest level of compliance fulfils the US obligation to protect the exclusive rights of authors of artistic and musical works. As we have noted before, Article 41 of TRIPs requires Members to maintain a legal and regulatory environment that permits effective action against acts of infringement. The US policy, which relies on the collective management organizations to issue licenses and does not involve a high level of policing of bars and restaurants by government agents, might or might not be consistent with this provision of TRIPs. But as the Arbitrators correctly point out, this question is not one that has been posed by the European Communities in any complaint under the DSU, nor is it one that an adjudicating body of the WTO has ruled upon.

Like the Arbitrators, we consider the legality of US enforcement procedures for copyright-protected music played in eating, drinking, and retail establishments to be beyond the scope of this paper. To answer the economic question of whether the US procedures are (close to) efficient in the light of the enforcement costs and the potential benefits from greater compliance would require evidence and data that are not readily available to us. Instead, we will proceed with our analysis - as the Arbitrators did by assuming that US enforcement procedures other than the one concerning the exemption of small eating, drinking, and retail establishment are legal, since they have not been shown to be otherwise.

By taking the objective of TRIPs to be the achievement of global efficiency in the creation of intellectual property, and by assuming that US enforcement procedures are legal and thus consistent with this objective, we are forced to conclude that the optimal level of investment in new musical works by $\mathrm{EC}$ songwriters and performing artists is one that equates the expected costs of creating music with the expected rewards. Thus, under the assumed legality of the enforcement procedures, EC artists would have faced the appropriate incentives to create new works had their prospective rewards been those they could legitimately have expected to obtain but for the (illegal) amendment to Section 110(5) of the US Copyright Act.

Accordingly, we concur with the Arbitrators when they write in paragraph 3.24 of the Award that they "consider the benefits which they should take into account in this case as those which the European Communities 
could reasonably expect to accrue to it under Articles 11bis(1)(iii) and 11(1)(ii)" of the Berne Convention. These benefits match the injury that EC rights holders have suffered as a result of the demonstrated US violation of TRIPs. Assuming that US practices and procedures in its copyright laws are legal except for those that the WTO Panel found to be otherwise, a compensatory payment equal to the benefits lost by reason of the illegal actions would enable the European Communities to restore the appropriate incentives for the creation of intellectual property. ${ }^{11}$

\subsection{The calculations}

It is difficult to find fault with the detailed calculations performed by the Arbitrators to estimate the revenues that would have been paid to EC rights holders but for the enactment of Section 110(5)(B). The Arbitrators identified the conceptually correct magnitude of impaired benefits as being the royalty fees that would have been distributed to the EC rights holders or their designated representatives as a result of payments made by eating, drinking, and retail establishments that had been exempted from royalties on radio and television music based on their small size or the nature of their broadcasting equipment. Constrained by the limited availability of data, the Arbitrators made a reasonable effort to find an empirical analogue to this unobserved magnitude.

We feel, however, that the Arbitrators toiled under unreasonable and unfortunate constraints with respect to their access to data and evidence. The Arbitrators recognized this problem themselves. They wrote in paragraph 4.15 of the Award that

In this case, the Arbitrators have encountered particular difficulties due to the lack of precise information available. This problem originated either in the actual absence of specific data for the type of transactions concerned (payment of royalties to E.C. rights holders) or in the lack of co-operation on the part of some of the private entities which may have had the information. The absence of sufficiently specific information played a major role in the choices made by the Arbitrators with respect to methodology and calculations.

${ }^{11}$ One qualification here is that appropriate incentives for the creation and performance of musical works will only be restored if the European Communities distribute the moneys collected from the United States in compensation to those whose rights have been abrogated. But there is nothing in the DSU that requires the European Communities to use the funds received in compensation in this way. 
And they reiterated in paragraph 4.35 that

... [the Arbitrators'] ability to make an accurate calculation has been limited by the fact that the data provided to them by the two parties were incomplete and included many estimations and assumptions. In their submissions, both parties have recognized this problem, noting that some of the relevant data are in the possession of private parties. As explained above, we sent letters to the two main US CMOs, ASCAP and BMI, requesting actual data on their collections and distributions that would have enabled us to base our calculations on specific information. In response to those letters, we obtained some information from BMI, but due to the conditions attached to its use, we decided not to include it in the record of the case.

We note that Article 13 of the DSU grants the WTO adjudicating bodies the authority to gather information from any source they deem appropriate. The Arbitrators made use of this provision in the case at hand, but only to a limited extent. Because the parties had instructed the Arbitrators to resolve the matter expeditiously, the Arbitrators felt constrained in their ability to exercise powers under Article 13 of the DSU.

Here we confront one of the most frequently debated aspects of the DSU: can a WTO adjudicating body disregard a mutually agreed request by the disputing parties in the interest of delivering a more reasoned verdict? Or must the adjudicating body accept that 'the dispute belongs to the parties'? Arguments can be made on both sides.

Inasmuch as the reports by the adjudicating bodies provide guidance in subsequent disputes, the WTO has an abiding interest in the accuracy and intellectual coherence of its reports. But a broad interpretation of the maxim of non ultra petita might suggest that the adjudicating bodies have little discretion to deviate from the requests of the disputants. Proponents of such an approach can find good support for their argument in the letter of Article 25.1 of the DSU: "Expeditious arbitration ... can facilitate the solution of certain disputes that concern issues that are clearly defined by both parties" (emphasis added).

We prefer to interpret this maxim as applying only to the issues that the adjudicating body has been asked to resolve, and not to extend unduly so as to prejudge the powers of the WTO adjudicating bodies under the DSU. That is, in our view the maxim non ultra petita should be understood to provide a limit as to what (i.e. which claims and arguments) can be discussed by the WTO adjudicating bodies but not a limit as to how claims and arguments will be entertained. Article 13 of the DSU gives the Arbitrators a clear and unambiguous right to gather the information 
they need to assess impaired benefits. The Appendix to the DSU contains more hortatory language (which therefore is of lesser legal standing) that an adjudicating body's work should be finished within a pre-specified time period. Accordingly, we feel that the Arbitrators should have asserted their rights under Article 13 to delay their decision until the necessary data had become available. ${ }^{12}$

\subsection{Punitive compensation}

We believe that the Arbitrators were correct not to award punitive compensation in this case. From a legal perspective, the Arbitrators could have relied on the maxim of non ultra petita to exclude punitive payments, inasmuch as the European Communities had not suggested that compensation include any amount for punitive purposes and thus the Arbitrators were constrained by an established principle of international law not to recommend compensation in excess of what had been requested. Instead, the Arbitrators declined to award punitive compensation based on their understanding that the award should not exceed their estimate of the EC benefits nullified or impaired. We find this justification to be faulty, because the DSU allows for any "mutually agreeable compensation" and does not thereby exclude payments for punitive purposes. Since the parties themselves can agree to compensation that includes a portion for punitive reasons, there is no legal basis for excluding such an award by the Arbitrators when the injured Member requests it.

However, from an economic perspective, we do not believe that punitive compensation would be warranted in this case. In general, punitive damages have a role to play in contract enforcement when the parties understand reasonably well whether their potential actions are legal or not but the actions taken are difficult to verify by their partners and by third parties. Then punitive levies can be used as a tool to discourage opportunistic behavior. In this case, the consistency of Sections 110(5)(A) and 110(5)(B) with TRIPs was not well understood before the dispute

12 We are mindful of the fact that the WTO contract is an agreement between governments, and that the WTO adjudicating bodies lack the legal means to ensure that private institutions in the United States or elsewhere will act in a cooperative manner as concerns the timely provision of data. However, this does not mean that a WTO body should always succumb to a request by the disputants to produce a report expeditiously and, as a result of this request, forfeit its rights under Article 13 of the DSU. Indeed, if the parties to the dispute truly are interested in a speedy resolution of a dispute, they have the ability to facilitate the process by obliging their nationals (private parties) to cooperate. 
was brought to the WTO Panel. Indeed, the Panel found that one of these provisions was not in violation of US obligations under TRIPs. Since the Agreement was new and its interpretation still open to question, it cannot be said that the United States was attempting to act in a clearly illegal way when it amended its Copyright Act in $1998 .{ }^{13}$ Nor can it be argued that the US action, once taken, was difficult to verify. The US legislation was publicly announced and readily observable to the European Communities and to the WTO adjudicating bodies.

\subsection{Retroactive compensation}

Insofar as the Arbitrators meant to compensate the European Communities only for the lost benefits that occurred after the dispute was referred for arbitration, we believe that they erred in assessing the appropriate time dimension for their award. Our argument has both legal and economic dimensions. On the legal side, it is a reasonably settled issue in public international law that remedies can be retroactive to the time when the violation(s) began. ${ }^{14}$ In the particulars of this case, there is nothing that excludes retroactive compensation, because the DSU allows for any mutually agreeable compensation and the parties did not specify in their proposals to the Arbitrators the time period over which their estimates of annual losses ought to apply. ${ }^{15}$

From an economic perspective, we have argued that the objectives of the Arbitrators ought to be to estimate the losses suffered by EC rights holders by reason of the offending US legislation. In doing so, they would

${ }^{13}$ Moreover, it should be emphasized that the exclusions applied not only to royalties that otherwise would be paid to EC rights holders, but also to royalties that otherwise would be paid to US rights holders. Indeed, although we have no evidence on this, we strongly suspect that US music publishers and artists lost far more by reason of the amendment than their EC counterparts. Thus, it is likely the case that the US legislation was not motivated by an intentional desire to abrogate US obligations under TRIPs, but rather by purely domestic considerations.

${ }^{14}$ However, with only one exception - the case of Australia - Subsidies Provided to Producers and Exporters of Automotive Leather, Recourse to Article 21.5 of the DSU (WTO Doc. WT/DS126 of February 20, 2000) - the WTO adjudicating bodies have preferred prospective remedies to retroactive remedies in all cases that have been brought before them since the signing of the DSU. It should be noted that the WTO contract does not make retroactive compensation illegal. Rather, the contract provides no specific normative guidance on this issue.

${ }^{15}$ Had the European Communities specified that it was seeking compensation only for the period after the referral of the matter to arbitration, the Arbitrators would have been constrained by the maxim of non ultra petita not to include any compensation for benefits lost in earlier periods. 
make good the legitimate expectations of these rights holders at the time the Agreement was signed, and thereby would ensure that the rewards to creativity provide the appropriate incentives for the generation of new musical works. Surely, it was legitimate for EC songwriters, musicians, and musical publishers to expect royalties from their copyrighted works not only in the period from July 23, 2001 onward, but also from the period between January 26, 1999 (when the amendment to the US copyright law went into effect) and July 23,2001 . Only by providing retroactive compensation can the rewards in the event of a violation of the Agreement match the hypothetical rewards in the but-for world.

\section{Conclusions}

To conclude, we summarize our main findings. We believe that the WTO Arbitrators were legally justified and economically correct in using a butfor standard in calculating the compensation that would be paid to the European Communities in recognition of the US violation of TRIPs. The Arbitrators sought to estimate the royalties that EC rights holders would have received from American collective management organizations had the United States not illegally exempted certain eating and drinking establishments from the obligation to license certain forms of music. The European Communities had argued instead for an amount that equals the total royalties that these establishments should have paid in a hypothetical world with 100 percent enforcement. The Arbitrators noted that intellectual property rights are not self-enforcing, and that enforcement entails real costs. By replacing the reward that EC songwriters, musical performers, and musical publishers could legitimately have expected to receive, the Arbitrators were restoring the optimal incentives for creative activity under the working hypothesis that US enforcement procedures are consistent with the objectives of TRIPs.

We emphasize, however, that the legality of the US enforcement procedures has not been resolved in this case. The United States tolerates a system in which only about one quarter of the bars and restaurants that ought to be liable for royalty payments actually acquire licenses for the copyrighted music they play. Such a system may or may not be consistent with the US obligation under Article 41 of TRIPs to "ensure that enforcement procedures ... are available under [each country's] law so as to permit effective action against any act of infringement of intellectual property rights covered by this Agreement." Surely, 100 percent enforcement should not be expected in the light of the transaction costs that are 
involved. The Arbitrators argued that they did not have any mandate to judge the legality of the US enforcement procedures. We too lack sufficient information to judge what level of compliance would be sufficient to meet the requirements of TRIPs. We consider this issue to be unresolved.

Finally, we have considered whether the Arbitrators were correct to exclude any levy for punitive purposes in the award to the European Communities and whether they should have taken a retroactive perspective for purposes of calculating the size of the compensation payment. We argued that a punitive levy would not be appropriate in this case, because the illegal actions of the United States were not hidden and not clearly intended to violate an international agreement. As for the time dimension, the legitimate expectations of EC rights holders would have included royalty payments throughout the period following the signing of TRIPs. Therefore, the Arbitrators' award should have included an amount for retroactive compensation.

\section{References}

Chin, Judith and Grossman, Gene M. 1990. Intellectual Property Rights and North South Trade. Pp. 90-107 in R.W. Jones and A.O. Krueger, eds. The Political Economy of International Trade. Cambridge MA: Basil Blackwell Publishers.

Deardorff, Alan V. 1992. Welfare Effects of Global Patent Protection. Economica 59: $35-51$.

Diwan, Ishac and Rodrik, Dani. 1991. Patents, Appropriate Technology, and NorthSouth Trade. Journal of International Economics 30: 27-48.

Grossman, Gene M. and Lai, Edwin L.-C. 2002. International Protection of Intellectual Property. NBER Working Paper No. 8704.

Helpman, Elhanan. 1993. Innovation, Imitation, and Intellectual Property Rights. Econometrica 61: 1247-1280.

Maskus, Keith E. 2000. Intellectual Property Rights in the Global Economy. Washington DC: The Institute for International Economics.

Scotchmer, Suzanne. 2002. The Political Economy of Intellectual Property Treaties. NBER Working Paper No. 9114. 